\title{
Some thinking about electrical professional courses teaching
}

\author{
Guo Panfeng \\ China Three Gorges University College \\ Yichang, China \\ gpf1226@163.com
}

\author{
Li Zhenxing \\ China Three Gorges University College \\ Yichang, China \\ 18800506@qq.com
}

\begin{abstract}
Electrical professional courses characteristics is described in this article, then the problems existing in the teaching and student's attitude toward professional elective course were analyzed and discussed. And on this basis, by changing the professional elective course teachers structure, improve the understanding of the importance of professional elective courses, the introduction of positive energy and emotional education, the teaching idea of electrical specialty elective course teaching were put forward some thinking.
\end{abstract}

Keywords-electrical; elective courses; teaching, thinking

\section{INTRODUCTION}

With the reform of credit system in college and universities and the requirements of quality-oriented education of college students, Universities are usually arrange professional required course credits to achieve, at the same time, they will make some study about the professional elective credits and outline requirements to extend students' professional knowledge [1]. In this way, the third grade students will need to select the corresponding credit professional elective courses. In the author's college of electrical engineering as an example, students think professional courses what is of great help to one's deceased father grind or employment is very important. So, students learn professional class seriously. Obviously, this is beyond doubt. But for the electrical professional elective courses, such as power electronic device, the application of power electronics in power system, electrical automation equipment and so on curriculum, they will be unlike professional course of treatment. Although these courses have been formulate outline and credit constraints, in the mind of teachers and students values tend to lack. This will lead to a series of problems. This article will discuss the teaching of electrical professional elective course.

\section{The PRoBlems of THE EleCtrical ELECTIVE COURSE TEACHIING}

\section{A. The characteristics of the electrical professional elective courses}

In this paper, we will be according to the author teaches professional elective course "power electronic equipment and system" as an example to analyze the characteristics of course.
On the one hand, the content of this course is more and widely. Professional elective course which is the expansion and extension of specialized courses, just as its name implies, is often based on the professional basic course and specialized course. If students want to understand the optional courses, they will need to learn the specialized courses include: analog electronic technology, digital electronic technology, automatic control principle, power electronic technology, and so on. Electrical professional students all know that the course content is difficult to understand. If the foundation is not solid or forgotten knowledge, students will feel boring in class. This will lead to the class having no efficiency.

On the other hand, this professional elective course's theoretical and abstract thinking is more complex. Every professional elective course need to several other courses as a support, like the foregoing electronic technology foundation and power electronic technology; these two courses in the process of learning theoretical are more complex. The optional courses are based on the device, in order to control as the main line to learn. When students face control module which is composed of numerous electronic devices to play imagination and to understand the control process, this abstract thinking is difficult to set up. In addition, most electrical class professional elective course have no teaching practice, however, practice classes in daily life can be put to use, and helps to stimulate students interest in learning. And let students really feel the importance of specialized courses and practical. However, because of course nature, within the limited class hours and under the experimental condition, the practice is hard to open and also difficult to play its proper role and effect.

In a word, electric professional elective course is a comprehensive course which has many characteristics, such as content, content, more difficult, boring.

\section{B. The problem of the electrical professional elective courses}

First is the rationality of the professional elective course instructor arrangement. To "Power electronic devices and systems" this course, it consists of three parallel classes, and there are three teachers undertake independently. Teachers should be familiar with the professional basic course and familiar with industrial practice, because of the nature of the courses and characteristics [2]. If this course teaching task is full and effective completion, therefore, this needs our teachers 
have certain experience. But, often as a result of teacher resources, or the time of the course arrangement and so on factors, this can lead to individual young teachers on the platform, to grant the strong comprehensive specialized elective course. So, the teacher arranged the rationality of the remains to be improved.

The second is attention degree which is teacher teaching is not enough. The electrical professional elective course is opened in the university three grades next semester. Teachers will think it is an elective course, not as important as professional course. So, they will be from psychologically contempt. In the process of preparation, not rigorous attitude or cut corners phenomenon exist. At the same time, the part of the elective courses teachers' general requirements for students is relatively loose. This will lead to classroom attendance and relatively loose classroom discipline [3].

In addition, it is the choice of the ways of teaching target and teaching. Professional elective course is 32 hours. It is usually for a limited time to finish the more content, which puts forward high demands on teachers and students. So teachers in teaching process, often use of multimedia courseware for the interpretation of the non-computer majors, and students will have intention to not intentional of to listen.

\section{Students attitude towards electrical professional elective courses}

Elective courses due to low class, demand is generally low. So, many students bring the "mixed credits" or "mixed grade point" attitude to class. At the same time, some students think that professional elective course teachers' demand is low. Therefore, students will produce "anyway can have thought". These all influence the teaching quality of elective courses [4]. In addition, the professional elective course is opened in junior year next semester, as students learn professional class and ready to take an examination of grinding time. Even many times some students go over class classroom classes, books, or watch one's deceased father grind all elective course what the teacher was saying.

\section{SOME ELECTRICAL PROFESSIONAL COURSETEACHING}

\section{A. Changing structure of teaching faculty}

Normally, each teacher will undertake a professional elective course independently. The teachers have high demands on professional basic course and experience. So, on the structure of teachers, we can take the measures like this: a) Select the relevant specialized course teachers to professional elective courses, such as, power electronic devices and systems, this course we can choose to teach teacher of teach this course of power electronic technology. So that we can make this optional courses teaching content targeted, and make full use of limited class hours teaching this course. b) The optional courses can choose courses cross the class teacher, like a professional introduction to class, so that we can improve the students' newness, also can increased the professional elective course of professional knowledge.

\section{B. Improving the cognition to the professional elective courses}

Teachers can use in other related professional foundation course, or in the usual communication, or the schools to professional means of preaching, and so on, to make students realize that professional elective courses to strengthen the training of the students' professional competence, which is of great significance. Professional elective courses set purpose is as follows: it can meet the needs of the current employment situation and broaden our professional knowledge. Most of the time, it can help to find a job, because a lot of employment unit requires a solid professional foundation, professional ability, professional competence should be highlighted more. Of course, the teacher attaches great importance to the professional elective course teaching, which can improve the students' professional ability and enhance their employment competitiveness role [5]. In addition, students through professional elective course of study, can improve the knowledge structure, form the knowledge system of the electric system, and even can be electrical professional comprehensive talent to serve the society.

\section{Introducing of positive energy and emotional education, building happy and harmonious atmosphere}

Regardless of how to develop the professional elective course outline, how to reduce the difficulty, there are the emphasis and difficulty of the course. So, there are always some difficult to understand an emphasis and difficulty of the content will make students want to give up their study. In the teaching process, the status of students, plus homework, to timely communication with students, so as to teachers can understand the student's confusion. How the communication is a science, it is worth our each teacher to think. Teachers should stand the perspective of students to communicate, to encourage students, difficult to understand the details of the content and increase the students self-confidence, introduce the positive energy.

Introduced the so-called emotional education, it is a kind of communication - communication of teachers and students [6]. Due to many colleges and universities implement of large or lectures in the class, teachers have no time or would not spend too much time to communicate with students. After the end of a semester, the teacher is very difficult to call out the names of most of the students in class. Actually, communicating with students not only in classroom, but also we can use QQ, fetion, MSN, and so on to communicate and communication network with students. Through the teaching of the author found that if a teacher can all students know this, their enthusiasm and initiative in class will be significantly different. They can have confidence and will trust the teacher. And this is a manifestation of emotional education. In addition, the teacher can take criticism education into full praise, encourage more, and increase the positive energy. For strong theoretical, compare the abstract knowledge explain, if students don't understand, to encourage they don't have to worry about, because knowledge itself is abstract, especially for students with poor foundation should be estimated. Perhaps a word from the teacher, the student will be suddenly enlightened, will have more confidence to learn. For the wrong answer questions in 
class the classmate, but also to encourage is given priority to, fully affirmed the student's answer.

In addition, teachers can have more humorous and vivid language during the classes. Doing this can be pushed the distance between the gaps with the students as much as possible. Because of electrical professional elective courses' nature, the teaching of the course will be boring, theoretical slightly stronger. If teachers scripted or screen according to the book are bound to cause students drowsy, the classroom efficiency is too low, so the appropriate interspersed with some humorous words, or send a humorous little jokes, will let the student spirit, into the thinking of teachers. So that can improve the classroom efficiency.

\section{Proper introduction of new teaching idea}

Teaching classroom now than ever before are not the same. Now the classroom learning knowledge is wide, but students get knowledge of the way is not only the classroom, so that the appropriate way to change teaching methods may be effective. Especially university electrical engineering third grade students, which are about to enter the fourth grade, will face to continue their studies in the study section of the road or step into the society employment. So, students tend to care about professional course learning process, not designed to control itself. In the teaching process, the teacher can use some teaching methods, such as the students to explain, discuss etc. These can fully mobilize the enthusiasm of the students, who can be participated in the classroom. In the lecture, the teacher can be contacted with the lesson example knowledge as the class introduction. This can arouse the students' interest, so that students feel the significance of learning. Teachers can also be appropriate to play video to show the current hot devices and systems, etc. In short, in the teaching mode, we can fully mobilize the enthusiasm of students, to achieve a diversified teaching mode, so that students have a certain understanding of the development of the future of the professional.

\section{CONCLUSIONS}

Electrical professional courses for the electrical professional students, is can improve the knowledge of students in the electrical industry a comprehensive discipline, which should has a more important position. But as a result of many factors, in many colleges and universities professional elective courses is not taken seriously, as a means of "credits". Based on the electrical professional courses teaching as an example, the professional elective course in colleges and universities teaching was put forward some thinking for other college educators to discuss and correct.

\section{REFERENCES}

[1] Zhang Qiong. Thinking about strengthening the professional elective course teaching in colleges [J]. Journal of Xiangtan Normal University (SOCIAL SCIENCE EDITION), 2003, (5).

[2] Lv Honglang, Wang Xusheng. Reform and practice of the examination method of the elective course in Colleges and Universities [J]. Adult education in china, 2006, (7).

[3] Li Shengli. Some Problems of Specialized Elective Courses Teaching and Several Advices [J]. CHINESE GEOLOGICAL EDUCATION, 2009 (1) : :46-47

[4] Li Daoxi. Problems and Counter measures of Specialized Elective Course Teaching in Colleges and Universities [J]. Journal of North China Institute of Water Conservancy and Hydroelectric Power (Social Science), 2010(26):170-172

[5] Zhu Ziming, Pan Huahua, Jin Shulan. On the importance and practical significance of the professional elective course [J]. 2010, Theory, pp: 266-267

[6] Cao Xianhui. The problems of the relationship between teachers and students in colleges and universities and the countermeasures [J]. Education to explore. 2012(3):42-45 